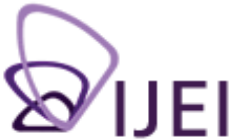

International Journal for Educational Integrity

\title{
Editorial Volume 4(1)
}

Welcome to Volume 4(1) of the International Journal for Educational Integrity.

Last year finished in a frenzy of activity at the $3^{\text {rd }}$ Asia-Pacific Conference on Educational Integrity: Creating a Culture of Integrity, held at the University of South Australia, 7-8 December 2007. Professor Cathy Small from Northern Arizona University opened the conference with her thought-provoking presentation, 'The culture of the university: Challenges and implications for academic integrity', based on her undercover year as a college freshman. This was followed by thirty-five papers and workshops, including excellent keynote addresses by Professor Brian Martin from the University of Wollongong, Professor Bob Birrell from Monash University, and Emeritus Professor Robert Crotty from the Ethics Centre of South Australia. The full proceedings are available in CD-Rom by contacting tracey.bretag@unisa.edu.au. The next conference, scheduled for late 2009, will be held at the University of Wollongong in New South Wales, Australia. Further details will be provided in the coming months via this journal and the Asia-Pacific Forum on Educational Integrity.

I would like to take this opportunity to welcome members of a newly established Editorial Board of the IJEl: Robert Crotty, Ethics Centre of South Australia; Fiona Duggan, Higher Education Academy JISC Academic Integrity Service, UK; Rebecca Moore Howard, Syracuse University; Brian Martin, University of Wollongong; Helen Marsden, University of Canberra; Don McCabe, Rutgers University; Miguel Roig, St. John's College, New York; and Daniel Wueste, Center for Academic Integrity, Clemson University.

The current issue of the journal offers an eclectic mix of international and interdisciplinary insights. Kate Chanock, an Academic Language and Learning (ALL) adviser from La Trobe University in Melbourne, explores survey data which sought to provide an explanation for why many students unwittingly plagiarise. Chanock then shares her own teaching practice as a means of 'mediating the gap between students' and lecturers' understandings of the purposes of attribution in scholarly writing".

Sue McGowan from the University of South Australia, and Margaret Lightbody from the University of Adelaide, provide insights from Commerce as they make the case for ongoing plagiarism education for English as an additional language (EAL) students. McGowan and Lightbody outline an assignment "specifically developed to assist EAL students in a second-year financial accounting course delivered in Hong Kong, to develop an understanding of plagiarism issues within the context of their study discipline".

The final two papers come from African nations, and inevitably overshadow some of the integrity issues confronting Western academics. While this is not the first time that African scholars have submitted work for consideration to the journal, this is the first time that authors, reviewers and editors have worked hand-in-hand, over multiple revisions and submissions, and an extended time period, to ensure that the final work meets international academic publishing standards. We trust that readers will agree that the message being told in both papers is important, and that academics in more privileged institutions have a responsibility to collaborate with our colleagues to ensure that these stories reach a wide audience.

Anthony Nwaopara, Anthony Ifebhor and Frank Ohiwerei from Ambrose Alli University Ekpoma in Nigeria, dare to speak out about the shocking breaches of academic integrity occurring everyday in Nigeria. 'Proliferating illiteracy in the universities: A Nigerian

The International Journal for Educational Integrity is available online at:

http://www.ojs.unisa.edu.au/journals/index.php//JEl/

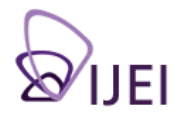


perspective' argues that the current crisis in the Nigerian educational system is "contributing to a downward spiral in academic standards, and in particular...to decreasing literacy among Nigerian students". The authors provide a rare inside view of the underfunded Nigerian education system which exists in a broad culture of corruption, and is dominated by examination fraud, violence on campus, sexual harassment and a range of entrenched social problems. One recommendation, among others offered by the authors to ameliorate this situation, is for university authorities, administrators, lecturers, students and parents to maintain a strict code of personal ethics in all educational endeavours.

By fortuitous coincidence, this suggestion is taken up by Blessing Chapfika from Masvingo State University, Zimbabwe, in his paper, 'The role of integrity in higher education'. Chapfika maintains that 'virtue ethics' as opposed to rules-based approaches to ethics, plays a crucial role in higher education. Without referring to specific behaviours or cases, Chapfika makes a strong case for the centrality of the key virtue - integrity - for both teachers and learners.

I do hope you enjoy the current issue of the International Journal for Educational Integrity, and encourage you to consider submitting a paper for review. The December issue of the journal will be a special issue, guest edited by Dr Fiona Duggan, from the Higher Education Academy JISC Academic Integrity Service in the United Kingdom. Dr Duggan is seeking papers focusing on supporting and promoting academic integrity in European Higher Education Institutions. Please send your submissions directly to her at fhduggan@gmail.com. The submission deadline is 8 September 2008.

Other papers not related to the Special Issue, can be submitted to the journal via the automatic tracking system, or directly to me at tracey.bretag@unisa.edu.au.

\section{Tracey Bretag, IJEI Editor}

April 2008

\section{List of reviewers 2007-2008}

Bambaccus, Mary. University of South Australia

Barthels, Alex. University of Technology, Sydney

Cadman, Kate. University of Adelaide

Di Matteo, Don. University of South Australia

Dick, Martin. RMIT, Melbourne

Duggan, Fiona. JISC Advisory Service, U.K.

East, Julianne. La Trobe University

Foster, Gigi. University of South Australia

Harris, Howard. University of South Australia

Hastie, Brianne. University of South Australia

Higgins-Desbiolles, Freya. University of South Australia

Hinton, Leone. Central Queensland University

Kennelly, Robert. University of Canberra

Li, Laubi. University of South Australia

Marsden, Helen. University of Canberra

Matthews, Brian. Flinders University

Morrow, Margaret. SUNY Plattsburgh, New York, U.S.A.

Muller, Robert. Flinders University

O'Callaghan, Terry. University of South Australia

Palmer, Carolyn. Flinders University

Sharman, Jason. Griffith University

Smith, Erica. Charles Sturt University

Van Hooft, Stan. Deakin University

Wache, Dale. University of South Australia

Winefield, Tony. University of South Australia. 